\title{
Infrared Spectroscopic Detection of Biosignatures at Lake Tírez, Spain: Implications for Mars
}

\author{
Louisa J. Preston,, ${ }^{1, \star}$ Rebeca Barcenilla, ${ }^{1,2}$ Lewis R. Dartnell, ${ }^{2}$ \\ Ezgi Kucukkilic-Stephens, ${ }^{3}$ and Karen Olsson-Francis ${ }^{3}$
}

\begin{abstract}
The detection of potential biosignatures with mineral matrices is part of a multifaceted approach in the search for life on other planetary bodies. The 2020 ExoMars Rosalind Franklin rover includes within its payload three IR spectrometers in the form of ISEM (Infrared Spectrometer for ExoMars), MicrOmega, and Ma-MISS (Mars Multispectral Imager for Subsurface Studies). The use of this technique in the detection and characterization of biosignatures is of great value. Organic materials are often co-deposited in terrestrial evaporites and as such have been proposed as relevant analogs in the search for life on Mars. This study focuses on Ca-sulfates collected from the hypersaline Tírez Lake in Spain. Mid infrared and visible near infrared analysis of soils, salt crusts, and crystals with green and red layering indicative of microbial colonization of the samples was acquired from across the lake and identified the main mineral to be gypsum with inputs of carbonate and silica. Organic functional groups that could be attributed to amides and carboxylic acids were identified as well as chlorophyll; however, due to the strong mineralogical absorptions observed, these were hard to unambiguously discern. Taxonomical assignment demonstrated that the archaeal community within the samples was dominated by the halophilic extremophile Halobacteriaceae while the bacterial community was dominated by the class Nocardiaceae. The results of this research highlight that sulfates on Mars are a mixed blessing, acting as an effective host for organic matter preservation but also a material that masks the presence of organic functional groups when analyzed with spectroscopic tools similar to those due to fly on the 2020 ExoMars rover. A suite of complementary analytical techniques therefore should be used to support the spectral identification of any candidate extraterrestrial biosignatures. Key Words: IR spectroscopy-Mars-Sulfate—Biosignature-Lake Tírez. Astrobiology 20, 15-25.
\end{abstract}

\section{Introduction}

T HE SEARCH FOR LIFE on other worlds is a multifaceted endeavor. One of its key elements is the detection of potential biosignatures preserved within mineral structures that could indicate the presence of extinct or extant life. Celllike morphologies and isotopic signatures resulting from metabolic reactions can also be produced by entirely abiotic mechanisms. The organic components comprising cells and their associated materials can be preserved either as degraded molecules trapped in mineralized cells or as disseminated molecules chemically bonded to mineral particles. Therefore, correlative detection of organic compounds is required before a case for life can be conclusively made.
Historically, the search for life on Mars has focused on the search for water. The presence of mineral phases such as phyllosilicates, sulfates, and opals (Carter et al., 2013, 2015; Sun and Milliken, 2015), tells a story of aqueous alteration processes occurring on the surface and subsurface of early Mars (e.g., Moore and Howard, 2005; Baker, 2006; Ehlmann et al., 2011, Michalski et al., 2013). Now the search includes the detection of organic molecules on or beneath the surface of Mars. Carbon is abundant as an atmospheric gas and can also be found in the form of carbon dioxide ice and carbonate minerals (Ehlmann et al., 2008; Boynton et al., 2009; Morris et al., 2010). In addition, organic matter has now been found preserved within the 3 billion-year-old mudstones of Gale Crater (Eigenbrode et al., 2018). This

\footnotetext{
${ }^{1}$ Department of Earth and Planetary Sciences, Birkbeck College, University of London, London, UK.

${ }^{2}$ Department of Life Sciences, University of Westminster, London, UK.

${ }^{3}$ Department of EEES, The Open University, Walton Hall, Milton Keynes, UK.

*Current affiliation: Department of Earth Sciences, The Natural History Museum, London, UK.
} 
evidence indicates that complex organic molecules have been present and possibly available for life for most of Mars' history, which suggests that this planet has supported multiple habitable environments during the Noachian and early Hesperian periods (Vago et al., 2017).

In astrobiology, minerals and organic molecules are intimately linked: minerals provide surfaces to support, concentrate, and preserve organic molecules, and act as templates for prebiotic reactions. This work focuses on sulfates, a class of hydrated minerals detected on Mars. Sulfates have been mapped by the ESA Mars Express OMEGA instrument (Arvidson et al., 2005; Bibring et al., 2005; Gendrin et al., 2005) and the Compact Reconnaissance Imagine Spectrometer for Mars (CRISM) on board Mars Reconnaissance Orbiter (MRO) (Pelkey et al., 2007; Wiseman et al., 2010), and detected by the NASA rovers (Squyres et al., 2004; Gellert et al., 2006; Morris et al., 2006; Ehlmann and Edwards, 2014; McAdam et al., 2014). Varieties identified include iron sulfates (such as jarosite and ferricopiapite), magnesium sulfates (such as kieserite), and calcium sulfates (such as gypsum, basanite, and anhydrite). Among these, Casulfates are more stable under martian conditions compared to other varieties. They have been found in veins and the lower strata of Mount Sharp at Gale Crater (Grotzinger et al., 2012; Nachon et al., 2014; Vaniman et al., 2014; Rapin et al., 2016), at Endeavor Crater, the Columbia Hills at Gusev Crater (Squyres et al., 2006; Yen et al., 2008), and at the North and South Poles of Mars. Sulfates are also not just restricted to ancient terrains; the well-mixed dust that covers most surfaces on Mars has high concentrations of sulfates, at an average concentration of $5.82 \mathrm{wt} \%$ (Gellert et al., 2004).

In this paper, we report on the mid infrared (MIR) and near infrared (NIR) spectroscopic study of the hypersaline lake environment, Tírez Lake, in Spain. On Earth, hypersaline environments impose severe stresses on endogenous microorganisms, such as high osmotic pressures and potentially low (aw 0.75) water activities (Grant, 2004). Despite this, life has been found surviving at an unexpected level of diversity over a wide range of salt concentrations (Ley et al., 2006). The potential of hypersaline environments and the evaporitic minerals they precipitate to preserve life and its biomolecules over geologically significant timescales makes Tírez Lake a compelling habitat to investigate biomolecular signatures, and for the search for life vestiges on Earth and beyond.

\section{Materials and Methods}

\subsection{Tírez Lake}

Tírez Lake is located in the province of Toledo, region of Castilla-La Mancha, central Spain, and covers an area of 0.8 $\mathrm{km}^{2}$. It is one of several endorheic hypersaline lakes originating under semi-arid conditions in the Iberian Peninsula (Fig. 1a) and is home to a thriving community of sulfatereducing and methanogenic microorganisms, including haloarchaea and halobacteriaceae (Montoya et al., 2011, 2013). Its salt composition is determined by the inflow of water coming from Triassic evaporites, dolomites, and calciumsulfate marls of Tertiary age (Prieto-Ballesteros et al., 2003). During the summer, salt content in the water column can reach saturation, causing crystallization of salts such as gypsum, halite, epsomite, and hexahydrate, with high con- centrations of $\mathrm{SO}_{4}{ }^{2-}, \mathrm{Cl}^{-}, \mathrm{Ca}^{2+}$, and $\mathrm{Mg}^{2+}$ recorded (PrietoBallesteros et al., 2003). During these months, the sediments are found to have a circumneutral $\mathrm{pH}$ around 6.9 (Fig. 1b).

Samples were collected during the summer of 2017 when dry conditions and high temperatures during the season had caused complete evaporation of the lake. Sampling occurred at regular intervals from the interior of the lake progressively toward the shore. This provided an environmental gradient designed to identify any changes in the mineralogy and potentially the microbiology of Tirez sediments. Four representative areas will be focused on here. Material collected from area 1 (Fig. 1c) is from the interior of the lake and is composed of white and brown sediments, dry crust, and soil from under the dry crust. The samples from areas 2 and 3 (Fig. 1d, 1e) are a mixture of dry salt crusts and mud located at two midway points between the interior and shoreline. Area 4 samples collected from the shore comprise dry crust (Fig. 1f) and whole salt crystals displaying subsurface zones of green and red coloration (Fig. 2). Samples were collected with sterile scoops, placed into sterile falcon tubes and in sterilized sampling bags (Whirl-Pak) and immediately sealed. The samples were kept at ambient temperature during field work, transportation, and storage on return to the laboratory. For analysis, evaporitic samples were ground in an agate pestle and mortar to a fine powder (grains varied in size to reflect the variable grain size distributions on Mars), handled minimally and only with nitrile gloves.

\subsection{Fourier transform infrared spectroscopy}

Fourier transform infrared spectroscopy has been used successfully for the identification of microorganisms and microscopic biological structures (Naumann et al., 1991; Schmitt and Flemming, 1998; Igisu et al., 2009, Preston et al., 2015 and references therein), including analysis of bacterial samples by Helm et al. (1991), comparison of Tírez brines with Galileo NIMS spectra data by PrietoBallesteros et al. (2003), and discrimination of halophilic microorganisms by Güven et al. (2015).

Mid infrared spectra were obtained with a Thermo Scientific Nicolet iS5 FTIR Spectrometer and an iD5 SingleBounce attenuated total reflectance (ATR) attachment equipped with a diamond crystal, housed in the Planetary Spectroscopy Laboratory at Birkbeck, University of London. Reflectance measurements, published as absorbance units, were obtained over a spectral range of $500-4000 \mathrm{~cm}^{-1}$ at a resolution of $4 \mathrm{~cm}^{-1}$. A diamond calibration standard was used and atmospheric water $\left(\mathrm{H}_{2} \mathrm{O}\right)$ and carbon dioxide $\left(\mathrm{CO}_{2}\right)$ subtractions made. No further processing of data (e.g., smoothing or Fourier self-deconvolution) was used, to avoid the introduction of artifacts. Band positions are reported simply as the observed maxima, rather than maxima obtained from second derivations or from curve fits. Six analyses were taken of each powdered sample of Tírez sediments which were re-homogenized after each spectral acquisition to obtain an accurate spectral profile of the material and its associated organic functional groups.

\subsection{Visible near infrared (Vis-NIR) spectroscopy}

Near infrared spectroscopy has been used to study the mineralogy of a wide variety of soil profiles and minerals ranging from volcanic glass alteration products and clays 


\section{a}

b

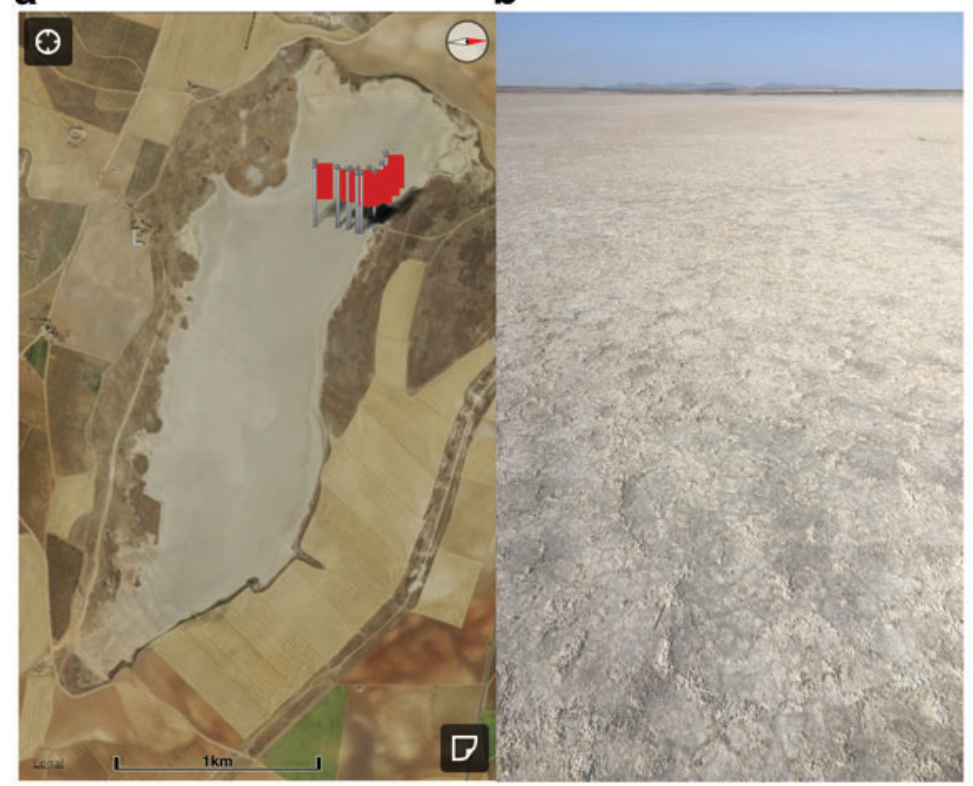

C

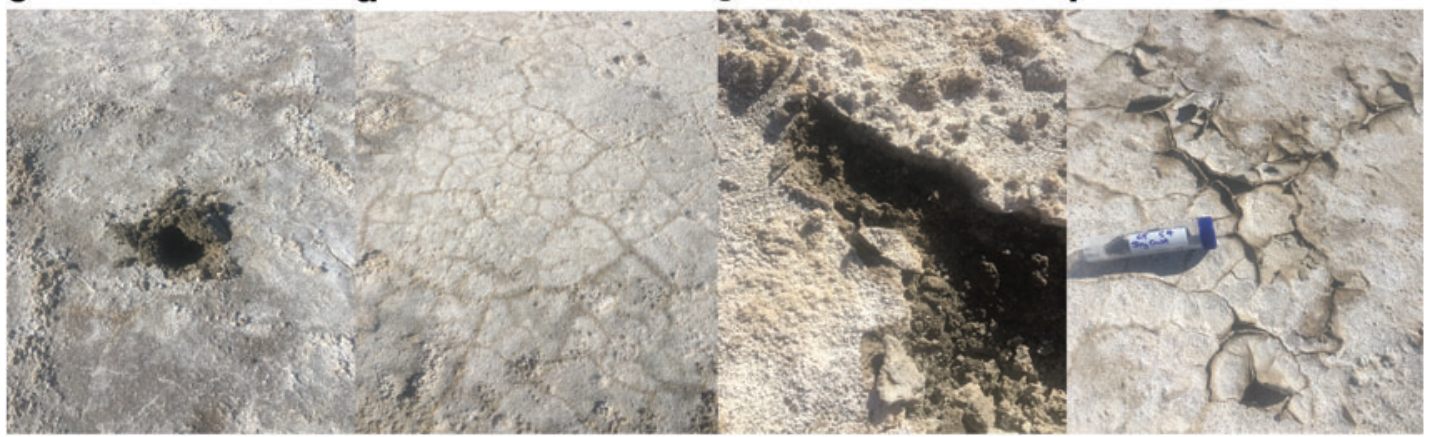

FIG. 1. (a) Aerial view over Tírez Lake with area and individual sampling spots labeled by red flags. (b) Photograph on the ground of the sampling area. (c) Site 1 soil sampling. (d) Site 2 salt crust with desiccation patterns visible. (e) Site 3 salt crust and subsurface soil sampling. (f) Site 4 dry salt crusts. Color images are available online.

FIG. 2. Magnified image of gypsum crystals and salt crust from site 4 displaying red and green microbial endolithic layers. Color images are available online.

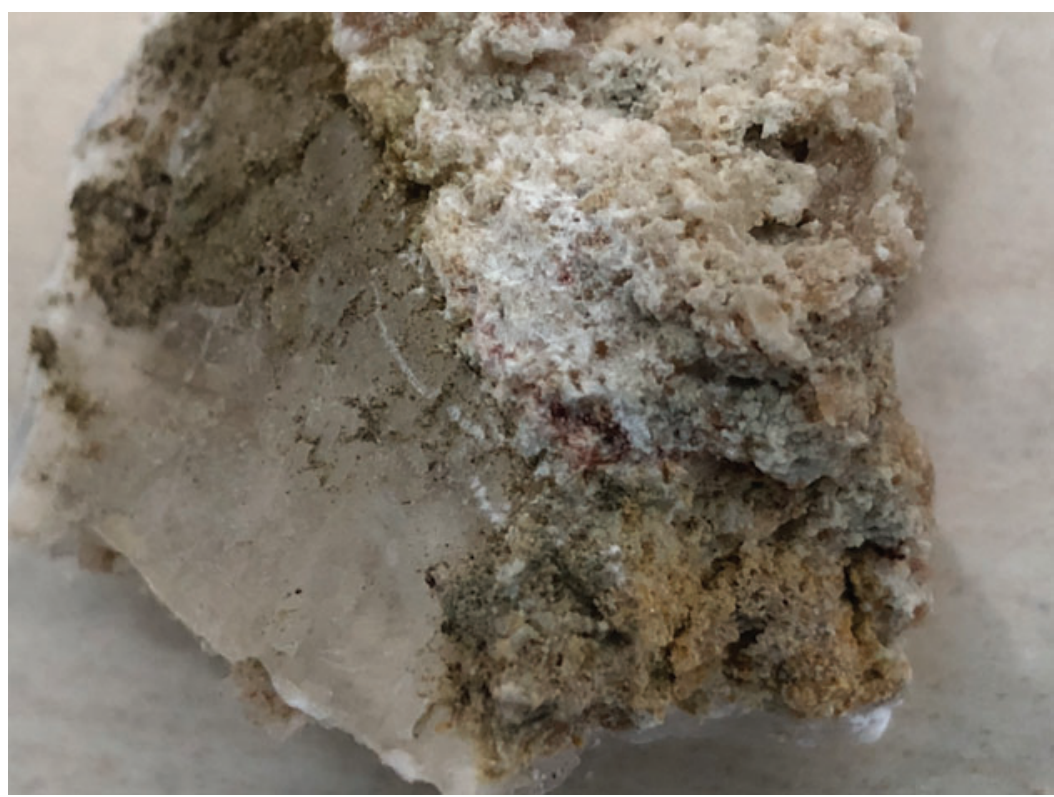


(e.g., Orenberg and Handy, 1992; Viscarra Rossel et al., 2009) to sulfates (e.g., Cloutis et al., 2006). It has also been included in remote sensing payloads to map the mineralogy of planetary surfaces including that of Europa (McCord et al., 1998), Mars (Bibring et al., 2005), and the Moon (Foing et al., 2006).

Three analyses of each unprocessed sample were performed by using an RxSpec $700 \mathrm{Z}$ spectrometer housed at the University of Westminster, London. NIR reflectance spectra were obtained over a range of $0.35-2.5 \mu \mathrm{m}$.

\subsection{Nucleic acid analysis}

Prior to extraction, the samples $(n=3)$ were rinsed in sterilized MiliQ water to dissolve the outer layer of the salt and then sterilized by using the method described in the work of Jaakkola et al. (2014), except the $\mathrm{NaCl}$ was replaced with $\mathrm{NaSO}_{4}$. The samples were crushed with a sterilized pestle and mortar, and $5 \mathrm{~g}$ of sample was added to $30 \mathrm{~mL}$ of sterilized MiliQ water. The samples were vortexed for $10 \mathrm{~min}$, and any undissolved material was precipitated by centrifugation, at $4000 \times g$ for $5 \mathrm{~min}$. The supernatant (containing the nucleic acids) was removed and directly added to Amincon Ultra $0.5 \mathrm{~mL}$ centrifugal filter units $(30$ $\mathrm{kDA})$. Twelve filters were used in total to accommodate the volume of supernatant. The filters were centrifuged at $12,000 \times g$ for $5 \mathrm{~min}$ at $4^{\circ} \mathrm{C}$, inverted, and placed into a clean sterilized centrifuge tube. The nucleic acids were eluted by centrifugation again, as before, and eluted volume was adjusted to $50 \mu \mathrm{L}$.

The DNA was extracted by using the XS buffer protocol, as described in Leuko et al. (2008) and pooled $(n=3)$. The $\mathrm{V} 4$ to the V5 of the hypervariable region of the 16S rRNA gene was amplified with universal primers using PCR conditions that have previously been described (Olsson-Francis et al., 2016). The PCR products were purified with ethanol and sequenced using the Illumina NovaSeq platform ( $\mathrm{Mr}$ DNA, US). The QIIME2 pipeline was used to process the raw data. All chimeric sequences were removed by using the DADA2 noise algorithm, and the remaining sequences were trimmed ( $<15 \mathrm{bp}$ and $>270 \mathrm{bp}$ ). The sequences were clustered into amplicon sequences variants (ASVs), and phylogeny was assigned using Scikit-learn classifier, which was based on the Greengenes database (DeSantis et al., 2006) (confidence threshold of $p=0.7$ ).

\section{Results}

Mid infrared and visible near infrared spectra averaged from each site of interest are shown in Fig. 3a and 3b, respectively. Only one Vis-NIR spectrum is presented, as all analyses taken showed the same features. The fundamental vibrational modes of gypsum $\left(\mathrm{CaSO}_{4} \cdot 2 \mathrm{H}_{2} \mathrm{O}\right)$ were found to correspond to the main peaks in the MIR and the overtone and combinational modes to the absorption bands in the Vis-NIR. The assignments for the mineralogical components of the samples are consistent with previous studies such as Liu (2018).

\subsection{Mineralogy}

In the MIR, the strongest absorption peaks in samples from site 1 to 4 were found at 1002,1001, 1003, and $1105 \mathrm{~cm}^{-1}$ respectively. This corresponds to the $v_{1}$ symmetric and $v_{3}$ asymmetric stretching vibrational modes of $\mathrm{SO}_{4}$ tetrahedra. Two antisymmetric $\mathrm{v}_{4}$ bending vibrations of $\mathrm{SO}_{4}$ tetrahedra were also observed around $664-667$ and $596 \mathrm{~cm}^{-1}$. Within the gypsum spectrum there are also stretching and bending $\mathrm{v}_{2}$ vibrational modes of C-O of carbonate located at 1455 and between 872 and $877 \mathrm{~cm}^{-1}$. The presence of water in the gypsum can be discerned by peaks in the region near 3500 and $1600 \mathrm{~cm}^{-1}$. The $\mathrm{v}_{1}$ symmetric stretching vibrational modes of $\mathrm{H}_{2} \mathrm{O}$ are located around $3400 \mathrm{~cm}^{-1}$ and the $\mathrm{v}_{3}$ antisymmetric stretching vibrational modes at 3520 and $3640 \mathrm{~cm}^{-1}$. There are two peaks caused by the $\mathrm{O}-\mathrm{H}$ bending vibrational modes located at 1682 and $1619 \mathrm{~cm}^{-1}$. This double peak indicated there are two distinct crystallographic types of water-one hydrogen bonded to the sulfate ions and one linked to calcium ions. In addition to gypsum, there are also vibrational modes indicative of carbonate ions $\left(\mathrm{CO}_{3}{ }^{2-}\right)$ within samples from sites 1 and $2 . \mathrm{A} \mathrm{v}_{1}$ stretching vibration is located at $1082 \mathrm{~cm}^{-1}$, and the $\mathrm{v}_{4}$ vibration is split with peaks observed at 746 and $711 \mathrm{~cm}^{-1}$. A minor $\mathrm{v}_{3}$ stretching vibration of $\mathrm{CO}_{3}{ }^{2-}$ ions is observed in samples from site 4 . In samples from site 3 , a strong shoulder is observed on the $1003 \mathrm{~cm}^{-1}$ peak, assigned to the $\mathrm{Si}-\mathrm{O}$ asymmetric stretching vibration of $\mathrm{SiO}_{4}$ tetrahedra.

In the NIR, all spectra displayed the same absorption bands indicative of gypsum, albeit at variable intensities. Reflectance minima were observed at 2.22, 2.27, and $2.33 \mu \mathrm{m}$ due to the combinational mode of $\mathrm{v}_{1} \mathrm{H}_{2} \mathrm{O}+\mathrm{v}_{3} \mathrm{SO}_{4}$. A strong absorption at 1.94 and $1.97 \mu \mathrm{m}$ is that of $\mathrm{H}_{2} \mathrm{O}$ combinations $\left(\mathrm{v}_{2}+\mathrm{v}_{3}\right) \mathrm{H}_{2} \mathrm{O}$ vibrational modes produced by structural water molecules, at $1.75 \mu \mathrm{m}$ due to an $\mathrm{OH}$ combination, and at $1.18 \mu \mathrm{m}$ of the combination of the $\mathrm{H}_{2} \mathrm{O}$ bending fundamental and the first overtone of the $\mathrm{OH}$ stretching fundamental. A diagnostic yet complicated band shape of gypsum is observed between 1.4 and $1.5 \mu \mathrm{m}$ as a reflectance minima triplet caused by $\mathrm{OH}$ stretching.

\subsection{Organics}

There are very few absorptions in the MIR that can be unequivocally attributed to organic molecules within the samples. A discussion later will look into the difficulties of organic versus mineral absorption band interpretations. There are a few bands, however, that cannot be attributed to the mineralogical host of the samples and so have the potential to be due to organic materials. Across all samples there are absorption bands at 1747 and $1795 \mathrm{~cm}^{-1}$ which may be caused by $\mathrm{C}=\mathrm{O}$ stretching vibration of a carbonyl group. In addition, a minor peak at $1434 \mathrm{~cm}^{-1}$ potentially of a C-O-H in-plane bending functional group is observed. A number of absorptions could be assigned to nitrogen-bearing functional groups of amides and amines. In samples from sites 1,3 , and 4 a $\mathrm{C}=\mathrm{O}$ stretching band is observed at 1651$1655 \mathrm{~cm}^{-1}$ sandwiched between absorption bands around 1681 and $1621 \mathrm{~cm}^{-1}$. These may be created by the presence of a primary amide within the samples. In samples from sites 3 and 4 located toward the edge of the lake, a peak around $1563 \mathrm{~cm}^{-1}$ is observed of the $\mathrm{N}-\mathrm{H}$ in-plane bending vibration of secondary amides. In all spectra, a shoulder peak is observed around $3236 \mathrm{~cm}^{-1}$. This may be due to the $\mathrm{N}-\mathrm{H}$ stretching vibrational mode of secondary amines. Finally, in spectra from sites 1 and 2 in the center of the lake, twin absorptions at 746 and 711 may be attributed to the $\mathrm{N}-\mathrm{H}$ out-of-plane bending vibration of secondary amides and the 

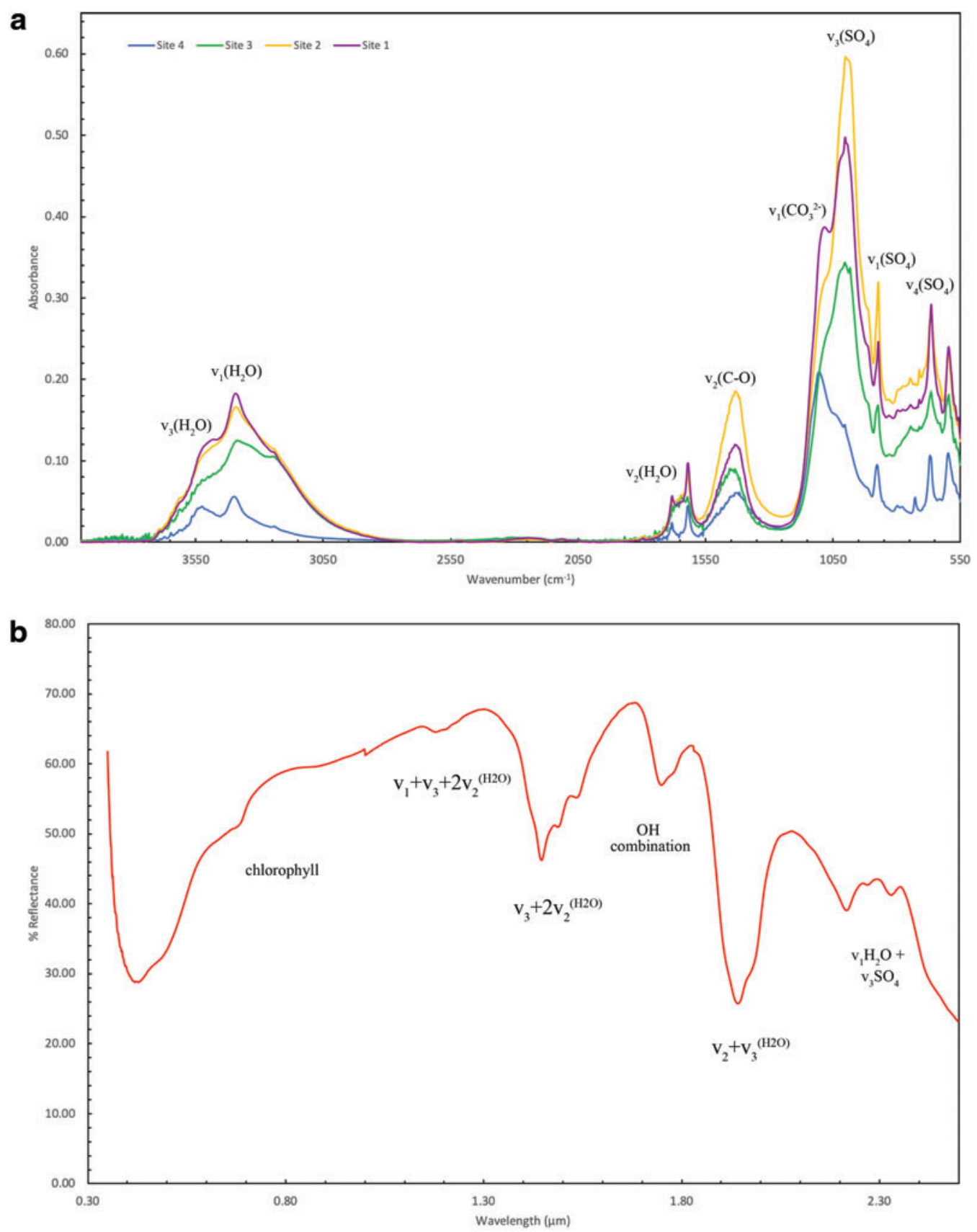

FIG. 3. (a) Mid infrared spectra from sites 1-4 with the main mineralogical functional group vibrations identified. (b) A Vis-NIR spectrum from site 4 with the main mineralogical combinational and overtone absorptions identified. The absorption band of chlorophyll at $0.67 \mu \mathrm{m}$ is also highlighted. Color images are available online.

$\mathrm{NH}_{2}$ out-of-plane bending vibration of primary amides; however, it is more likely that of carbonate ions.

In the Vis-NIR there is a strong drop in reflectance shortward of $\sim 0.8 \mu \mathrm{m}$ which corresponds to the "red edge" of chlorophyll, and a chlorophyll absorption feature is observed at $\sim 0.67 \mu \mathrm{m}$. There are weaker features below this wavelength that can probably be attributed to chlorophyll and other photoprotective pigments such as carotenoids. Absorption bands near 1.75 and $2.2-2.35 \mu \mathrm{m}$ were observed that could be identified to arise from the combination and/or overtone modes of the fundamental $\mathrm{CH}$ stretching vibration, which although a possibility in these samples are more likely consistent with fundamental vibrational modes and overtones/combination bands of gypsum.

\subsection{Composition of the microbial community}

Partial sequencing of the 16S rRNA gene was used to identify the major bacterial and archaeal classes within the sample. Quality filtration of the raw data resulted in a total of 50954 sequences (medium read length $390 \mathrm{bp}$ ). Due to the length of the sequences, identification was carried out to a 


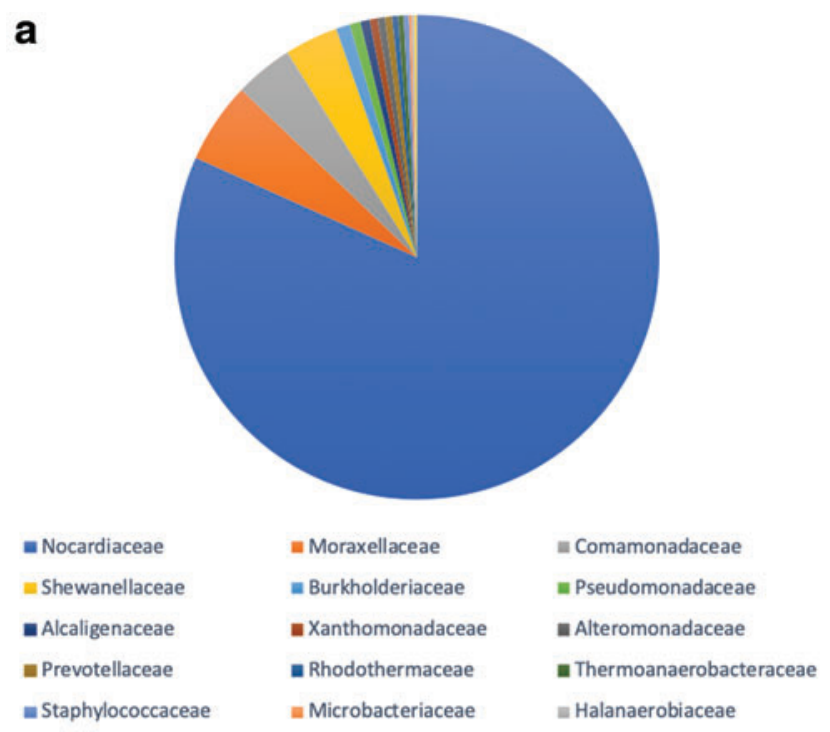

\section{b}

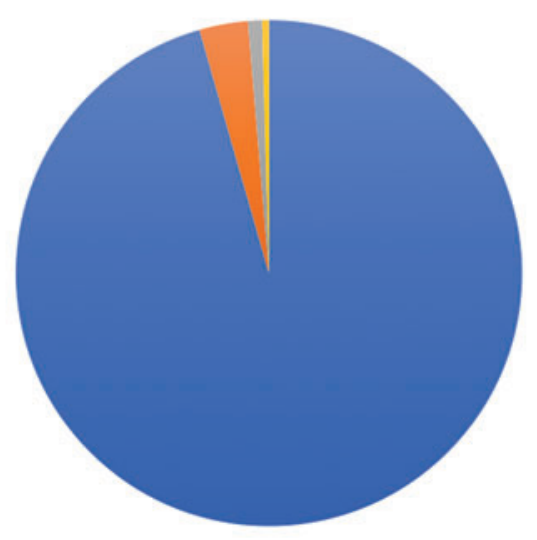

= Halobacteriaceae $=$ Methermicoccaceae $=$ Thermoproteaceae $=$ Thaumarchaeota

FIG. 4. Relative abundance of the most common microbial (a) and archaeal (b) families identified in evaporitic material collected from Tírez Lake. Color images are available online.

family level. Taxonomical assignment demonstrated that the archaeal community was dominated by Halobacteriaceae $(96 \%)$ while the bacterial community was dominated by the class Nocardiaceae (80\%), as shown in Fig. 4a and 4b.

\section{Discussion}

\subsection{The preservation of organics within gypsum}

The stability of any biosignature is dependent on its initial form, the matrix in which it is hosted, and the chemical and physical processes it is subjected to over time. Based on observations of terrestrial analog sites, there is a general consensus that sediments, evaporites, and hydrothermal systems provide the highest preservation potential for biosignatures. On Earth, entombment of biosignatures within mineral matrices constitutes one of the most efficient preservation mechanisms against degradation of both microorganisms and organic molecules. This occurs through mineralization processes, including those driven by evaporation and precipitation, and enrichment inside mineral matrices as evidenced within sedimentary rocks and phyllosilicate minerals. Here the reduced permeability limits the exposure of entrapped organics to migrating fluids and gas, hence preserving their composition or structure. However, the persistence of the sedimentary (or other) material is a key factor for long-term preservation; if the mineralogical host matrix fails, then the entombed biosignatures may be lost. Sulfates, such as the gypsum described in this study, are not the optimal material for biosignature preservation, as they are susceptible to dissolution and mineralogical transformations; however, it has been observed that they can offer fossil stabilities for timescales of up to $1 \times 10^{6}$ years (Farmer and Des Marais, 1999) and more given the right conditions. The ultra-dry martian surface environment means that, after deposition, sulfate minerals such as gypsum on Mars are likely to persist for longer than on Earth with its extensive hydrological cycle.

Organic materials are often co-deposited in terrestrial evaporites and as such have been proposed as relevant analogs in the search for life on Mars. A study conducted by Aubrey et al. (2006) investigated concentrations of organic matter along with amino acids in natural terrestrial sulfate mineral samples. They found that sulfate minerals contain between $0.03 \%$ and $0.69 \%$ organic carbon as well as high parts-perbillion to low parts-per-million abundances of amino acids and their degradation products in samples dating back 40 million years. Evaporites have been found to preserve biosignatures by the entrapment of halophiles in fluid inclusions in both modern systems (Foster et al., 2010) and potentially those up to 250 million years old (Schubert et al., 2009). A study by Parnell et al. (2004) focused on microbial colonization in impact-generated hydrothermal crystalline gypsum deposits in the Haughton Crater, Devon Island, Canadian High Arctic. The authors demonstrated the presence of cyanobacteria in endolithic habitats located up to $50 \mathrm{~mm}$ from the crystal margins of clear gypsum crystals. These endolithic niches provide organisms with UV-shielding and temperature and water-activity moderation (Rothschild, 1990; Hughes \& Lawley, 2003; Wierzchos et al., 2006; Cockell et al., 2008).

The surface of Mars is a hostile place with extremes of atmospheric composition and pressure, temperature, and UV light irradiation. The preservation of potential biosignatures is governed by the threat of destruction by chemical oxidants, a high ionizing radiation environment, and the exposure age of the minerals they are contained within. In addition to a UVradiation refuge, evaporites can provide protection from oxidative surface processes (Stivaletta and Barbieri, 2009) and desiccation. Cloutis et al. (2007) found that minerals such as gypsum that contain structural $\mathrm{H}_{2} \mathrm{O}$ are more resistant to $\mathrm{H}_{2} \mathrm{O}$ loss under martian conditions than phyllosilicates. In a spectral study on gypsum endoliths exposed to the UV, anoxia, low pressure and desiccating conditions of Mars, Stromberg et al. (2014) found there was little change in the NIR spectra of the samples, with all major spectral features of both gypsum and chlorophyll preserved after exposure to UV irradiation equivalent to $\sim 300$ years at present martian surface conditions.

\subsection{The identification of organics within deposits at Tírez Lake}

It has been confirmed that the samples collected from Tírez Lake contain both halophilic bacteria and archaea, 
combined with visual evidence from site 4 of green and red horizons millimeters beneath the surface of the samples. Montoya et al. (2013) observed that archaeal communities in sediments at Tírez Lake showed higher diversity than within water samples from the area. They observed that around $40 \%$ of archaeal clones from both rainy and dry season sediments showed a high similarity with Halobacterium species with 16S rRNA gene sequence techniques showing a predominance of Haloarchaea, particularly members of the Halobacteriaceae. Halobacterium species, also generically known as halophiles, are commonly present in high-salinity environments and appear reddish due to the pigment bacterioruberin. It was also observed by Montoya et al. (2013) that Gammaproteobacteria are the dominant sequences in the sediments. Our study agrees with this observation, as the diversity within our own samples was dominated by bacteria.

The detection of organic matter in sulfate minerals, particularly gypsum, by using IR spectroscopy is challenging due to (i) the relative proportions of minerals and organics, with the former greatly outnumbering the latter, and (ii) the dominance of the sulfate ion vibrational modes and hydroxyl overtones in both the NIR and MIR spectra which occur at similar vibrational frequencies to many organic functional groups. Given the amplitude of the vibrational frequencies and excellent match between the observed spectra and previously documented examples cited above, it is logical to assign most absorbance data belonging to that of gypsum with minor contributions of carbonate and silica. This does not mean that there are no organic vibrations detectable within the sulfate samples, just that their absorptions are weaker and masked by the minerals present. There are a few peaks that are not mineralogically assignable and could belong to a few carboxyl group esters, and to some primary and secondary amides and amines. Despite the spectrally low organic content of the samples, amino acids are known to be excellent indicators for the presence of other organic material because they can be detected at very low levels, so their potential presence in the FTIR data may be significant. It should be noted that there is no observation of aliphatic structures as would be indicated by $\mathrm{C}-\mathrm{H}$ stretching vibrations in the region $2960-2850 \mathrm{~cm}^{-1}$. C-H bonds exist in virtually all organic compounds, and the $\mathrm{C}-\mathrm{H}$ stretch vibrations for methyl and methylene are the most characteristic in terms of recognizing a compound as organic. Since this region is free of any mineralogical overprint, if these aliphatic hydrocarbon vibrations were present within the samples, we would expect to see them here.

A successful interpretation of IR data both on Earth and Mars is based not only on the presence of particular bands within the spectrum but also the absence of other important bands. The $16 \mathrm{~S}$ rRNA analyses imply that organic molecules, as either part of the microbial community present or associated with them, should be expected to be detectable within the samples, so it is at least possible that we are seeing minor representations of these within the FTIR spectra of Tírez Lake. However, the lack of the $\mathrm{C}-\mathrm{H}$ stretching region, given its almost universal observation within organic compounds, implies that any organic assignments in the IR data should be viewed with caution and that the most likely interpretation is that the mineralogy of the samples is flooding the spectra.

\subsection{The identification of organics within gypsum on Mars}

The difficulty in distinguishing organics within a sulfatedominated system has profound implications for the search for evidence of past life on Mars. The robotic exploration of Mars has revealed that sulfate minerals are ubiquitous on the planet's surface (e.g., King and McLennan, 2010). The mineralogical transition on Mars from clay-rich to sulfaterich strata occurred as the atmospheric pressure on Mars decreased in the Late Noachian and the amount of sulfur dioxide degassing from lavas increased (Gaillard et al., 2013). Sulfate-forming conditions are likely to have persisted well into the Hesperian (Bibring et al., 2006; Gaillard et al., 2013). Analyses at both Rocknest and the Yellowknife Bay study site by the Chemistry and Mineralogy (CheMin) instrument of the Mars Science Laboratory found only calcium sulfates (Nachon et al., 2014; Downs et al., 2015, Vaniman et al., 2018), and oxidized sulfur species are widespread in martian meteorites, with calcium and magnesium sulfates being the most common forms (Gooding, 1992). On Earth, sulfate-forming conditions and sulfates themselves are inhabited by extremophilic microorganisms, so it is important to investigate the possibility of these deposits on Mars hosting evidence of similar life.

For in situ analysis of martian rocks and soils, including those rich in sulfates, organic matter can be, and so far has been, mainly identified by using thermal extraction protocols such as the Viking gas chromatograph-mass spectrometer (GC-MS), the Phoenix Thermal and Evolved Gas Analyzer (TEGA), and Mars Science Laboratory's Sample Analysis at Mars (SAM) instrument suite (Biemann et al., 1977; Grotzinger et al., 2012; Mahaffy et al., 2012). For the upcoming ExoMars rover, a similar process will be achieved through the Mars Organic Molecule Analyzer (MOMA) instrument (Goesmann et al., 2017). It has been shown, however, that, despite their high preservation potential, sulfate-bearing minerals pose a significant threat to the detection of organic compounds during thermal extraction. When sulfates decompose, they release oxygen on heating which may oxidize organic matter present in the sample of interest. A benefit of searching for biosignatures on Mars within gypsum and magnesium sulfates is that they are unlikely to yield oxygen at the temperatures commonly employed for the thermal extraction of organic matter, as under these conditions gypsum only dehydrates (West and Sutton, 1954; Gordon and Sephton, 2016). Due to the potential issues with organic detection and pyrolysis, however, it is important to be able to analyze and search for biosignatures by using nondestructive techniques, such as the IR spectroscopy utilized in this study.

The results of this work are very timely and appropriate given that the ExoMars Rosalind Franklin rover includes within its payload three IR spectrometers in the form of ISEM (Infrared Spectrometer for ExoMars), MicrOmega, and Ma-MISS (Mars Multispectral Imager for Subsurface Studies). ISEM is a pencil-beam spectrometer designed to study the mineralogical composition of the martian surface in the vicinity of the rover over the NIR spectral range between 1.15 and $3.3 \mu \mathrm{m}$ (Korablev et al., 2017). This range is highly sensitive to the hydration state of minerals and has the ability to observe, if present, strong absorption features 
associated with a number of PAH functional groups, particularly C-H molecules (Izawa et al., 2014). Absorptions can be observed at $1.69 \mu \mathrm{m}$ due to $\mathrm{CH}$ overtones, $\mathrm{N}-\mathrm{H}$ stretching overtones at $1.50 \mu \mathrm{m}$, and many further overtones and combination bands beyond $2.1 \mu \mathrm{m}$. MicrOmega is a Vis-NIR hyperspectral microscope located within the rover's analytical laboratory drawer. It is designed to characterize the texture and composition of martian samples with the ability to identify minerals, ices/frosts, and organics over the spectral range 0.5-3.65 $\mu \mathrm{m}$ (Bibring et al., 2017). Finally, there is the Ma-MISS experiment, a miniaturized spectrometer within the drill system that will perform IR spectral reflectance investigations in the $0.4-2.2 \mu \mathrm{m}$ range. Its goal is to study the subsurface of Mars, to characterize mineralogy and ices (De Sanctis et al., 2017).

One of the key findings in this study is the ability, or lack thereof, to observe known microbial components within the samples when using IR spectroscopy, most likely due to the dominance of gypsum. The amount of organic material needed for it to be spectrally visible has been investigated by ISEM-based simulations and by Dos Santos et al. (2016). In the later study, the authors studied the preservation of 25 amino acids spiked onto Mars analog minerals that included clays and the sulfates jarosite and gypsum under Mars UV conditions. They found that gypsum had the highest amino acid preservation when spiked with $10 \mathrm{M}$ amino acid solution equivalent to $1 \mathrm{mmol}$ of amino acid per gram of mineral, whereas at $1 \mathrm{M}$ solution no amino acids were detected in any of the samples, given the amino acid detection limit of the GC-MS used is $3 \mathrm{ppb}$. Overall, Dos Santos et al. (2016) found that the smectite and sulfate samples provided the best preservation of amino acids. In the case of gypsum this may be due to partial dissolution and recrystallization trapping the amino acids. It is important to consider the detection limits for Mars-bound spectrometers where it concerns multiple components, be it mineral mixtures, targets covered in wind-blown dust, or mineral-organic assemblages. Work by Korablev et al. (2017) has included studying the detection capabilities of the ISEM instrument. They found that detection limits are affected by factors such as grain size and the availability and intensity of diagnostic absorption bands as well as end-member abundances. They found for example that $1 \mathrm{wt} \%$ adenine is detectable in the NIR range of ISEM in the presence of $99 \mathrm{wt} \%$ nontronite or hematite. Further work needs to be done to study the spectral effects and detectability of sulfate-organic mixtures.

\section{Conclusions}

It appears that sulfates on Mars may represent something of a mixed blessing, acting as an effective host for organic matter preservation but also a potentially aggressive material that is difficult to analyze and masks the presence of organic functional groups when viewed using IR spectroscopy. In the case of Tírez Lake it is known that the sediments contain bacterial and archaeal communities, and as such spectral fingerprints of organic molecules should be visible. However, due to the band positions of the mineralogical host materials, these organic absorptions are hidden or are so small compared to the volume of sulfate present that their detection limit has been exceeded. Despite the difficulties encountered extrapolating organic molecular IR fingerprints from the gypsum at Lake Tírez, future astrobiology missions should not be discouraged from targeting Ca-sulfate deposits due to their high biosignature preservation potential. Instead, a suite of complementary analytical techniques should and will be used to support the spectral identification of extraterrestrial biosignatures in the presence of gypsum.

\section{Acknowledgments}

This work was supported by the UK Space Agency Aurora Fellowship grant ST/P001254/1 awarded to Louisa Preston.

\section{Author Disclosure Statement}

No competing financial interests exist.

\section{References}

Arvidson, R.E., Poulet, F., Bibring, J.-P., Wolff, M., Gendrin, A., Morris, R.V, Freeman, J.J., Langevin, Y., Mangold, N., and Bellucci, G. (2005) Spectral reflectance and morphologic correlations in eastern Terra Meridiani, Mars. Science 307: 1591-1594.

Aubrey, A., Cleaves, H.J., Chalmers, J.H., Skelley, A.M., Mathies, R.A., Grunthaner, F.J., Ehrenfreund, P., and Bada, J.L. (2006) Sulfate minerals and organic compounds on Mars. Geology 34:357-360.

Baker, V.R. (2006) Geomorphological evidence for water on Mars. Elements 2:139-143.

Bibring, J.-P., Langevin, Y., Gendrin, A., Gondet, B., Poulet, F., Berthé, M., Soufflot, A., Arvidson, R., Mangold, N., Mustard, J., and Drossart, P. (2005) Mars surface diversity as revealed by the OMEGA/Mars Express observations. Science 307: 1576-1581.

Bibring, J.-P., Langevin, Y., Mustard, J.F., Poulet, F., Arvidson, R., Gendrin, A., Gondet, B., Mangold, N., Pinet, P., Forget, F., Berthé, M., Bibring, J.-P., Gendrin, A., Gomez, C., Gondet, B., Jouglet, D., Poulet, F., Soufflot, A., Vincendon, M., Combes, M., Drossart, P., Encrenaz, T., Fouchet, T., Merchiorri, R., Belluci, G., Altieri, F., Formisano, V., Capaccioni, F., Cerroni, P., Coradini, A., Fonti, S., Korablev, O., Kottsov, V., Ignatiev, N., Moroz, V., Titov, D., Zasova, L., Loiseau, D., Mangold, N., Pinet, P., Douté, S., Schmitt, B., Sotin, C., Hauber, E., Hoffmann, H., Jaumann, R., Keller, U., Arvidson, R., Mustard, J.F., Duxbury, T., Forget, F., and Neukum, G. (2006) Global mineralogical and aqueous Mars history derived from OMEGA/Mars Express data. Science 312:400-404.

Bibring, J.-P., Hamm, V., Pilorget, C., Vago, J.L., and the MicrOmega Team. (2017) The MicrOmega investigation onboard ExoMars. Astrobiology 17:621-626.

Biemann, K., Oro, J., Toulmin, P., III, Orgel, L.E., Nier, A.O., Anderson, D.M., Simmonds, P.G., Flory, D., Diaz, A.V., Rushneck, D.R., Biller, J.E., and Lafleur, A.L. (1977) The search for organic substances and inorganic volatile compounds in the surface of Mars. J Geophys Res 82:4641-4658.

Boynton, W.V, Ming, D.W., Kounaves, S.P., Young, S.M.M., Arvidson, R.E., Hecht, M.H., Hoffman, J., Niles, P.B., Hamara, D.K., Quinn, R.C., Smith, P.H., Sutter, B., Catling, D.C., and Morris, R.V. (2009) Evidence for calcium carbonate at the Mars Phoenix landing site. Science 325:61-64. Carter, J., Poulet, F., Bibring, J.-P., Mangold, N., and Murchie, S. (2013) Hydrous minerals on Mars as seen by the CRISM 
and OMEGA imaging spectrometers: updated global view. $J$ Geophys Res Planets 118:831-858.

Carter, J., Loizeau, D., Mangold, N., Poulet, F., and Bibring, J.-P. (2015) Widespread surface weathering on early Mars: a case for a warmer and wetter climate. Icarus 248:373-382.

Cloutis, E.A., Hawthorne, F.C., Mertzman, S.A., Krenn, K., Craig, M.A., Marcino, D., Methot, M., Strong, J., Mustard, J.F., Blaney, D.L., Bell, J.F., and Vilas, F. (2006) Detection and discrimination of sulfate minerals using reflectance spectroscopy. Icarus 184:121-157.

Cloutis, E.A., Craig, M.A., Mustard, J.F., Kruzelecky, R.V, Jamroz, W.R., Scott, A., Bish, D.L., Poulet, F., Bibring, J.-P., and King, P.L. (2007) Stability of hydrated minerals on Mars. Geophys Res Lett 34, doi:10.1029/2007GL031267.

Cockell, C.S., McKay, C.P., Warren-Rhodes, K., and Horneck, G. (2008) Ultraviolet radiation-induced limitation to epilithic microbial growth in arid deserts-dosimetric experiments in the hyperarid core of the Atacama Desert. J Photochem Photobiol B Biol 90:79-87.

De Sanctis, M.C., Altieri, F., Ammannito, E., Biondi, D., De Angelis, S., Meini, M., Mondello, G., Novi, S., Paolinetti, R., Soldani, M., Mugnuolo, R., Pirrotta, S., Vago, J.L., and the Ma_MISS Team. (2017) Ma_MISS on ExoMars: mineralogical characterization of the martian subsurface. Astrobiology 17:612-620.

DeSantis, T.Z., Hugenholtz, P., Larsen, N., Rojas, M., Brodie, E.L., Keller, K., Huber, T., Dalevi, D., Hu, P., and Andersen, G.L. (2006) Greengenes, a chimera-checked 16S rRNA gene database and workbench compatible with ARB. Appl Environ Microbiol 72:5069-5072.

Dos Santos, R., Patel, M., Cuadros, J., and Martins, Z. (2016) Influence of mineralogy on the preservation of amino acids under simulated Mars conditions. Icarus 277:342-353. https:// doi.org/10.1016/J.ICARUS.2016.05.029

Downs, R.T. and the MSL Science Team. (2015) Determining mineralogy on Mars with the CheMin X-ray diffractometer. Elements 11:45-50.

Ehlmann, B.L. and Edwards, C.S. (2014) Mineralogy of the martian surface. Annu Rev Earth Planet Sci 42:291-315.

Ehlmann, B.L., Mustard, J.F., Murchie, S.L., Poulet, F., Bishop, J.L., Brown, A.J., Calvin, W.M., Clark, R.N., Des Marais, D.J., Milliken, R.E., Roach, L.H., Roush, T.L., Swayze, G.A., and Wray, J.J. (2008) Orbital identification of carbonatebearing rocks on Mars. Science 322:1828-1832.

Ehlmann, B.L., Mustard, J.F., Murchie, S.L., Bibring, J.-P., Meunier, A., Fraeman, A.A., and Langevin, Y. (2011) Subsurface water and clay mineral formation during the early history of Mars. Nature 479:53-60.

Eigenbrode, J.L., Summons, R.E., Steele, A., Freissinet, C., Millan, M., Navarro-González, R., Sutter, B., McAdam, A.C., Franz, H.B., Glavin, D.P., Archer, P.D., Mahaffy, P.R., Conrad, P.G., Hurowitz, J.A., Grotzinger, J.P., Gupta, S., Ming, D.W., Sumner, D.Y., Szopa, C., Malespin, C., Buch, A., and Coll, P. (2018) Organic matter preserved in 3-billion-year-old mudstones at Gale Crater, Mars. Science 360:1096-1101.

Farmer, J.D. and Des Marais, D.J. (1999) Exploring for a record of ancient martian life. J Geophys Res Planets 104:26977-26995.

Foing, B.H., Racca, G.D., Marini, A., Evrard, E., Stagnaro, L., Almeida, M., Koschny, D., Frew, D., Zender, J., Heather, J., Grande, M., Huovelin, J., Keller, H.U., Nathues, A., Josset, J.L., Malkki, A., Schmidt, W., Noci, G., Birkl, R., Iess, L., Sodnik, Z., and McManamon, P. (2006) SMART-1 mission to the Moon: status, first results and goals. Adv Space Res $37: 6-13$
Foster, I.S., King, P.L., Hyde, B.C., and Southam, G. (2010) Characterization of halophiles in natural $\mathrm{MgSO}_{4}$ salts and laboratory enrichment samples: astrobiological implications for Mars. Planet Space Sci 58:599-615.

Gaillard, F., Michalski, J., Berger, G., McLennan, S.M., and Scaillet, B. (2013) Geochemical reservoirs and timing of sulfur cycling on Mars. Space Sci Rev 174:251-300.

Gellert, R., Rieder, R., Anderson, R.C., Bruckner, J., Clark, B.C., Dreibus, G., Economou, T., Klingelhofer, G., Lugmair, G.W., Ming, D.W., Squyres, S.W., D'Uston, C., Wanke, H., Yen, A., and Zipfel, J. (2004) Chemistry of rocks and soils in Gusev Crater from the Alpha Particle X-ray Spectrometer. Science 305:829-832.

Gellert, R., Rieder, R., Brückner, J., Clark, B.C., Dreibus, G., Klingelhöfer, G., Lugmair, G., Ming, D.W., Wänke, H., Yen, A., Zipfel, J., and Squyres, S.W. (2006) Alpha Particle X-Ray Spectrometer (APXS): results from Gusev Crater and calibration report. J Geophys Res Planets 111, 10.1029/2005JE002555.

Gendrin, A. (2005) Sulfates in martian layered terrains: the OMEGA/Mars Express view. Science 307:1587-1591.

Goesmann, F., Brinckerhoff, W.B., Raulin, F., Goetz, W., Danell, R.M., Getty, S.A., Siljeström, S., Mißbach, H., Steininger, H., Arevalo, R.D., Buch, A., Freissinet, C., Grubisic, A., Meierhenrich, U.J., Pinnick, V.T., Stalport, F., Szopa, C., Vago, J.L., Lindner, R., Schulte, M.D., Brucato, J.R., Glavin, D.P., Grand, N., Li, X., van Amerom, F.H.W., and the MOMA Science Team. (2017) The Mars Organic Molecule Analyzer (MOMA) instrument: characterization of organic material in martian sediments. Astrobiology 17:655-685.

Gooding, J.L. (1992) Soil mineralogy and chemistry on Mars: Possible clues from salts and clays in SNC meteorites. Icarus 99:28-41. https://doi.org/10.1016/0019-1035(92)90168-7

Gordon, P.R. and Sephton, M.A. (2016) Organic matter detection on Mars by pyrolysis-FTIR: an analysis of sensitivity and mineral matrix effects. Astrobiology 16:831-845.

Grant, W.D. (2004) Life at low water activity. Philos Trans $R$ Soc Lond B Biol Sci 359:1247-1249.

Grotzinger, J.P., Crisp, J., Vasavada, A.R., Anderson, R.C., Baker, C.J., Barry, R., Blake, D.F., Conrad, P., Edgett, K.S., Ferdowski, B., Gellert, R., Gilbert, J.B., Golombek, M., Gómez-Elvira, J., Hassler, D.M., Jandura, L., Litvak, M., Mahaffy, P., Maki, J., Meyer, M., Malin, M.C., Mitrofanov, I., Simmonds, J.J., Vaniman, D., Welch, R.V., and Wiens, R.C. (2012) Mars Science Laboratory mission and science investigation. Space Sci Rev 170:5-56.

Güven, K., Albayrak, G., Guven, A., and Yazic, B. (2015) FT-IR for rapid discrimination of halophilic archaea and bacteria. $J$ Phylogenetics Evol Biol 3, doi:10.4172/2329-9002.1000147.

Helm, D., Labischinski, H., Schallehn, G., and Naumann, D. (1991) Classification and identification of bacteria by Fouriertransform infrared spectroscopy. Microbiology 137:69-79.

Hughes, K.A. and Lawley, B. (2003) A novel Antarctic microbial endolithic community within gypsum crusts. Environ Microbiol 5:555-565.

Igisu, M., Ueno, Y., Shimojima, M., Nakashima, S., Awramik, S.M., Ohta, H., and Maruyama, S. (2009) Micro-FTIR spectroscopic signatures of bacterial lipids in Proterozoic microfossils. Precambrian Res 173:19-26.

Izawa, M.R.M., Applin, D.M., Norman, L., and Cloutis, E.A. (2014) Reflectance spectroscopy (350-2500 nm) of solid-state polycyclic aromatic hydrocarbons (PAHs). Icarus 237:159-181. Jaakkola, S.T., Zerulla, K., Guo, Q., Liu, Y., Ma, H., Yang, C., Bamford, D.H., Chen, X., Soppa, J., and Oksanen, H.M. (2014) Halophilic archaea cultivated from surface sterilized 
middle-late Eocene rock salt are polyploid. PLoS One 9, doi: 10.1371/journal.pone.0110533.

King, P.L. and McLennan, S.M. (2010) Sulfur on Mars. Elements 6:107-112.

Korablev, O.I., Dobrolensky, Y., Evdokimova, N., Fedorova, A.A., Kuzmin, R.O., Mantsevich, S.N., Cloutis, E.A., Carter, J., Poulet, F., Flahaut, J., Griffiths, A., Gunn, M., Schmitz, N., Martín-Torres, J., Zorzano, M.-P., Rodionov, D.S., Vago, J.L., Stepanov, A.V., Titov, A.Y., Vyazovetsky, N.A., Trokhimovskiy, A.Y., Sapgir, A.G., Kalinnikov, Y.K., Ivanov, Y.S., Shapkin, A.A., and Ivanov, A.Y. (2017) Infrared spectrometer for ExoMars: a mast-mounted instrument for the rover. Astrobiology 17:542-564.

Leuko, S., Goh, F., Ibanez-Peral, R., Burns, B.P., Walter, M.R., and Neilan, B.A. (2008) Lysis efficiency of standard DNA extraction methods for Halococcus spp. in an organic rich environment. Extremophiles 12:301-308.

Ley, R.E., Harris, J.K., Wilcox, J., Spear, J.R., Miller, S.R., Bebout, B.M., Maresca, J.A., Bryant, D.A., Sogin, M.L., and Pace, N.R. (2006) Unexpected diversity and complexity of the Guerrero Negro hypersaline microbial mat. Appl Environ Microbiol 72:3685-3695.

Liu, Y. (2018) Raman, Mid-IR, and NIR spectroscopic study of calcium sulfates and mapping gypsum abundances in Columbus Crater, Mars. Planet Space Sci 163:35-41.

Mahaffy, P.R., Webster, C.R., Cabane, M., Conrad, P.G., Coll, P., Atreya, S.K., Arvey, R., Barciniak, M., Benna, M., Bleacher, L., Brinckerhoff, W.B., Eigenbrode, J.L., Carignan, D., Cascia, M., Chalmers, R.A., Dworkin, J.P., Errigo, T., Everson, P., Franz, H., Farley, R., Feng, S., Frazier, G., Freissinet, C., Glavin, D.P., Harpold, D.N., Hawk, D., Holmes, V., Johnson, C.S., Jones, A., Jordan, P., Kellogg, J., Lewis, J., Lyness, E., Malespin, C.A., Martin, D.K., Maurer, J., McAdam, A.C., McLennan, D., Nolan, T.J., Noriega, M., Pavlov, A.A., Prats, B., Raaen, E., Sheinman, O., Sheppard, D., Smith, J., Stern, J.C., Tan, F., Trainer, M., Ming, D.W., Morris, R.V., Jones, J., Gundersen, C., Steele, A., Wray, J., Botta, O., Leshin, L.A., Owen, T., Battel, S., Jakosky, B.M., Manning, H., Squyres, S., Navarro-González, R., McKay, C.P., Raulin, F., Sternberg, R., Buch, A., Sorensen, P., KlineSchoder, R., Coscia, D., Szopa, C., Teinturier, S., Baffes, C., Feldman, J., Flesch, G., Forouhar, S., Garcia, R., Keymeulen, D., Woodward, S., Block, B.P., Arnett, K., Miller, R., Edmonson, C., Gorevan, S., and Mumm, E. (2012) The Sample Analysis at Mars investigation and instrument suite. Space Sci Rev 170:401-478.

McAdam, A.C., Franz, H.B., Sutter, B., Archer, P.D., Jr., Freissinet, C., Eigenbrode, J.L., Ming, D.W., Atreya, S.K., Bish, D.L., Blake, D.F., Bower, H.E., Brunner, A., Buch, A., Glavin, D.P., Grotzinger, J.P., Mahaffy, P.R., McLennan, S.M., Morris, R.V., Navarro-González, R., Rampe, E.B., Squyres, S.W., Steele, A., Stern, J.C., Sumner, D.Y., and Wray, J.J. (2014) Sulfur-bearing phases detected by evolved gas analysis of the Rocknest aeolian deposit, Gale Crater, Mars. J Geophys Res Planets 119:373-393.

McCord, T.B., Hansen, G.B., Fanale, F.P., Carlson, R.W., Matson, D.L., Johnson, T.V., Smythe, W.D., Crowley, J.K., Martin, P.D., Ocampo, A., Hibbitts, C.A., and Granahan, J.C. (1998) Salts on Europa's surface detected by Galileo's Near Infrared Mapping Spectrometer. Science 280:1242-1245.

Michalski, J.R., Cuadros, J., Niles, P.B., Parnell, J., Deanne Rogers, A., and Wright, S.P. (2013) Groundwater activity on Mars and implications for a deep biosphere. Nat Geosci 6: 133-138.
Montoya, L., Lozada-Chavez, I., Amils, R., Rodriguez, N., and Marin, I. (2011) The sulfate-rich and extreme saline sediment of the ephemeral Tirez lagoon: a biotope for acetoclastic sulfate-reducing bacteria and hydrogenotrophic methanogenic archaea. Int J Microbiol 2011, doi:10.1155/2011/753758.

Montoya, L., Vizioli, C., Rodriguez, N., Rastoll, M.J., Amils, R., and Marin, I. (2013) Microbial community composition of Tirez lagoon (Spain), a highly sulfated athalassohaline environment. Aquat Biosyst 9, doi:10.1186/2046-9063-9-19.

Moore, J.M. and Howard, A.D. (2005) Large alluvial fans on Mars. J Geophys Res Planets 110, doi:10.1029/2004JE002352.

Morris, R.V., Klingelhöfer, G., Schröder, C., Rodionov, D.S., Yen, A., Ming, D.W., de Souza P.A., Jr., Fleischer, I., Wdowiak, T., Gellert, R., Bernhardt, B., Evlanov, E.N., Zubkov, B., Foh, J., Bonnes, U., Kankeleit, E., Gütlich, P., Renz, F., Squyres, S.W., and Arvidson, R.E. (2006) Mössbauer mineralogy of rock, soil, and dust at Gusev Crater, Mars: Spirit's journey through weakly altered olivine basalt on the plains and pervasively altered basalt in the Columbia Hills. J Geophys Res Planets 111, doi:10.1029/2005JE002584.

Morris, R.V., Ruff, S.W., Gellert, R., Ming, D.W., Arvidson, R.E., Clark, B.C., Golden, D.C., Siebach, K., Klingelhöfer, G., Schröder, C., Fleischer, I., Yen, A.S., and Squyres, S.W. (2010) Identification of carbonate-rich outcrops on Mars by the Spirit Rover. Science 329:421-424.

Nachon, M., Clegg, S.M., Mangold, N., Schröder, S., Kah, L.C., Dromart, G., Ollila, A., Johnson, J.R., Oehler, D.Z., Bridges, J.C., Le Mouélic, S., Forni, O., Wiens, R.C., Anderson, R.B., Blaney, D.L., Bell, J.F., III, Clark, B., Cousin, A., Dyar, M.D., Ehlmann, B., Fabre, C., Gasnault, O., Grotzinger, J., Lasue, J., Lewin, E., Léveillé, R., McLennan, S., Maurice, S., Meslin, P.-Y., Rapin, W., Rice, M., Squyres, S.W., Stack, K., Sumner, D.Y., Vaniman, D., and Wellington, D. (2014) Calcium sulfate veins characterized by ChemCam/Curiosity at Gale Crater, Mars. J Geophys Res Planets 119:1991-2016.

Naumann, D., Helm, D., and Labischinski, H. (1991) Microbiological characterizations by FT-IR spectroscopy. Nature 351:81-82.

Olsson-Francis, K., Pearson, V., Schofield, P., Oliver, A., and Summers, S. (2016) A study of the microbial community at the interface between granite bedrock and soil using a culture-independent and culture-dependent approach. $A d v$ Microbiol 6:233-245.

Orenberg, J. and Handy, J. (1992) Reflectance spectroscopy of palagonite and iron-rich montmorillonite clay mixtures: implications for the surface composition of Mars. Icarus 96: 219-225.

Parnell, J., Lee, P., Cockell, C.S., and Osinski, G.R. (2004) Microbial colonization in impact-generated hydrothermal sulphate deposits, Haughton impact structure, and implications for sulphates on Mars. Int J Astrobiol 3:247-256.

Pelkey, S.M., Mustard, J.F., Murchie, S., Clancy, R.T., Wolff, M., Smith, M., Milliken, R., Bibring, J.-P., Gendrin, A., Poulet, F., Langevin, Y., and Gondet, B. (2007) CRISM multispectral summary products: parameterizing mineral diversity on Mars from reflectance. J Geophys Res Planets 112, 10.1029/2006JE002831.

Preston, L.J., Johnson, D., Cockell, C.S., and Grady, M.M. (2015) Fourier transform infrared spectral detection of life in polar subsurface environments and its application to Mars exploration. Appl Spectrosc 69:1059-1065.

Prieto-Ballesteros, O., Rodríguez, N., Kargel, J.S., Kessler, C.G., Amils, R., and Remolar, D.F. (2003) Tírez Lake as a terrestrial analog of Europa. Astrobiology 3:863-877. 
Rapin, W., Meslin, P.-Y., Maurice, S., Vaniman, D., Nachon, M., Mangold, N., Schröder, S., Gasnault, O., Forni, O., Wiens, R.C., Martínez, G.M., Cousin, A., Sautter, V., Lasue, J., Rampe, E.B., and Archer, D. (2016) Hydration state of calcium sulfates in Gale Crater, Mars: identification of bassanite veins. Earth Planet Sci Lett 452:197-205.

Rothschild, L.J. (1990) Earth analogs for martian life. Microbes in evaporites, a new model system for life on Mars. Icarus 88: 246-260.

Schmitt, J. and Flemming, H.-C. (1998) FTIR-spectroscopy in microbial and material analysis. Int Biodeterior Biodegradation 41:1-11.

Schubert, B.A., Lowenstein, T.K., and Timofeeff, M.N. (2009) Microscopic identification of prokaryotes in modern and ancient halite, Saline Valley and Death Valley, California. Astrobiology 9:467-482.

Squyres, S.W., Grotzinger, J.P., Arvidson, R.E., Bell, J.F., Calvin, W., Christensen, P.R., Clark, B.C., Crisp, J.A., Farrand, W.H., Herkenhoff, K.E., Johnson, J.R., Klingelhöfer, G., Knoll, A.H., McLennan, S.M., McSween, H.Y., Morris, R.V., Rice, J.W., Rieder, R., and Soderblom, L.A. (2004) In situ evidence for an ancient aqueous environment at Meridiani Planum, Mars. Science 306:1709-1714.

Squyres, S.W., Arvidson, R.E., Blaney, D.L., Clark, B.C., Crumpler, L., Farrand, W.H., Gorevan, S., Herkenhoff, K.E., Hurowitz, J., Kusack, A., McSween, H.Y., Ming, D.W., Morris, R.V., Ruff, S.W., Wang, A., and Yen, A. (2006) Rocks of the Columbia Hills. J Geophys Res Planets 111, doi: 10.1029/2005JE002562.

Stivaletta, N. and Barbieri, R. (2009) Endolithic microorganisms from spring mound evaporite deposits (southern Tunisia). J Arid Environ 73:33-39.

Stromberg, J.M., Applin, D.M., Cloutis, E.A., Rice, M., Berard, G., and Mann, P. (2014) The persistence of a chlorophyll spectral biosignature from martian evaporite and spring analogues under Mars-like conditions. Int J Astrobiol 13:203-223.

Sun, V.Z. and Milliken, R.E. (2015) Ancient and recent clay formation on Mars as revealed from a global survey of hydrous minerals in crater central peaks. $J$ Geophys Res Planets 120:2293-2332.

Vago, J.L., Westall, F., Pasteur Instrument Teams, Landing Site Selection Working Group, and Other Contributors, Coates, A.J., Jaumann, R., Korablev, O., Ciarletti, V., Mitrofanov, I., Josset, J.-L., De Sanctis, M.C., Bibring, J.-P., Rull, F., Goesmann, F., Steininger, H., Goetz, W., Brinckerhoff, W., Szopa, C., Raulin, F., Westall, F., Edwards, H.G.M., Whyte, L.G., Fairén, A.G., Bibring, J.-P., Bridges, J., Hauber, E., Ori, G.G., Werner, S., Loizeau, D., Kuzmin, R.O., Williams, R.M.E., Flahaut, J., Forget, F., Vago, J.L., Rodionov, D., Korablev, O., Svedhem, H., Sefton-Nash, E., Kminek, G., Lorenzoni, L., Joudrier, L., Mikhailov, V., Zashchirinskiy, A., Alexashkin, S., Calantropio, F., Merlo, A., Poulakis, P., Witasse, O., Bayle, O., Bayón, S., Meierhenrich, U., Carter, J., García-Ruiz, J.M., Baglioni, P., Haldemann, A., Ball, A.J., Debus, A., Lindner, R., Haessig, F., Monteiro, D., Trautner, R., Voland, C., Rebeyre, P., Goulty, D., Didot, F., Durrant, S., Zekri, E., Koschny, D., Toni, A., Visentin, G., Zwick, M., van Winnendael, M., Azkarate, M., Carreau, C., and the ExoMars Project Team. (2017) Habitability on early Mars and the search for biosignatures with the ExoMars Rover. Astrobiology 17:471-510.

Vaniman, D.T., Bish, D.L., Ming, D.W., Bristow, T.F., Morris, R.V., Blake, D.F., Chipera, S.J., Morrison, S.M., Treiman,
A.H., Rampe, E.B., Rice, M., Achilles, C.N., Grotzinger, J.P., McLennan, S.M., Williams, J., Bell, J.F., Newsom, H.E., Downs, R.T., Maurice, S., Sarrazin, P., Yen, A.S., Morookian, J.M., Farmer, J.D., Stack, K., Milliken, R.E., Ehlmann, B.L., Sumner, D.Y., Berger, G., Crisp, J.A., Hurowitz, J.A., Anderson, R., Des Marais, D.J., Stolper, E.M., Edgett, K.S., Gupta, S., and Spanovich, N. (2014) Mineralogy of a mudstone at Yellowknife Bay, Gale Crater, Mars. Science 343, doi:10.1126/science.1243480.

Vaniman, D.T., Martínez, G.M., Rampe, E.B., Bristow, T.F., Blake, D.F., Yen, A.S., Ming, D.W., Rapin, W., Meslin, P.Y., Morookian, J.M., Downs, R.T., Chipera, S.J., Morris, R.V., Morrison, S.M., Treiman, A.H., Achilles, C.N., Robertson, F.K., Grotzinger, J.P., Hazen, R.M., Weins, R.C., and Sumner, D.Y. (2018) Gypsum, bassanite, and anhydrite at Gale Crater, Mars. Am Mineral 103:1011-1020.

Viscarra Rossel, R.A., Cattle, S.R., Ortega, A., and Fouad, Y. (2009) In situ measurements of soil colour, mineral composition and clay content by vis-NIR spectroscopy. Geoderma 150:253-266.

West, R.R., and Sutton, W.J. (1954). Thermography of Gypsum. J Americ Ceramic Society 37:221-224. https://doi.org/10.1111/ j.1151-2916.1954.tb14027.x

Wierzchos, J., Ascaso, C., and McKay, C.P. (2006) Endolithic cyanobacteria in halite rocks from the hyperarid core of the Atacama Desert. Astrobiology 6:415-422.

Wiseman, S.M., Arvidson, R.E., Morris, R.V., Poulet, F., Andrews-Hanna, J.C., Bishop, J.L., Murchie, S.L., Seelos, F.P., Des Marais, D., and Griffes, J.L. (2010) Spectral and stratigraphic mapping of hydrated sulfate and phyllosilicatebearing deposits in northern Sinus Meridiani, Mars. J Geophys Res Planets 115, doi:10.1029/2009JE003354.

Yen, A.S., Morris, R.V., Clark, B.C., Gellert, R., Knudson, A.T., Squyres, S., Mittlefehldt, D.W., Ming, D.W., Arvidson, R., McCoy, T., Schmidt, M., Hurowitz, J., Li, R., and Johnson, J.R. (2008) Hydrothermal processes at Gusev Crater: an evaluation of Paso Robles class soils. J Geophys Res Planets 113, doi:10.1029/2007JE002978.

\section{Address correspondence to: Dr. Louisa J. Preston UK Space Agency Aurora Research Fellow Department of Earth Sciences The Natural History Museum Cromwell Road, London, SW7 5BD}

$U K$

E-mail: louisajanepreston@gmail.com

Submitted 21 May 2019

Accepted 13 August 2019

$$
\begin{aligned}
& \text { Abbreviations Used } \\
\text { GC-MS }= & \text { gas chromatograph-mass spectrometer } \\
\text { ISEM }= & \text { Infrared Spectrometer for ExoMars } \\
\text { Ma-MISS }= & \text { Mars Multispectral Imager for } \\
& \text { Subsurface Studies } \\
\text { MIR }= & \text { mid infrared } \\
\text { NIR }= & \text { near infrared } \\
\text { Vis-NIR }= & \text { visible near infrared }
\end{aligned}
$$

